\title{
Post-translational modifications of HTLV-1 Tax \\ carboxy-terminal domain: role in cellular transformation
}

\author{
Julie Lodewick*, Anne Sophie Rinaldi, Françoise Bex \\ From 16th International Conference on Human Retroviruses: HTLV and Related Viruses \\ Montreal, Canada. 26-30 June 2013
}

Transformation of T lymphocytes by HTLV-1 is linked to the capacity of its oncoprotein Tax to interfere with cellular regulatory pathways, including control of cell cycle progression and inactivation of tumor suppressor p53. Tax is modified by a hierarchical sequence of posttranslational modifications that controls its intracellular localization and functions via crosstalk. Among these modifications, phosphorylation and acetylation occur at S336 and K346, respectively, in the carboxy-terminal domain of Tax, a domain involved in Tax transforming activity. We determined that the acetylation deficient K346R mutant had a markedly reduced capacity to transform Rat-1 fibroblast, as compared to the acetylmimetic K346Q mutant, which transformed Rat-1 cells as wild type Tax. This property correlated with the reduced capacity of mutant K346R to bypass inhibition of CDK4/cyclin D3 complexes by p21, resulting in its reduced capacity to stimulate $\mathrm{pRb}$ kinase activity of CDK4. Thus, acetylation at lysine residue 346 by the acetyltransferase p300 likely directly participates in the Tax transforming activity. We also determined that phosphorylation of Tax at the S336P motif involved the proline-directed serine/threonine kinase HIPK2. HIPK2 interacts with Tax and is recruited in the Tax nuclear bodies. Furthermore, the kinase activity of HIPK2 is required for efficient functional inactivation of p53 by Tax. These results indicate that modifications of the Tax carboxy-terminal domain control at least two critical functions in Tax transforming activities: stimulation of cell cycle progression through G1/S via activation of CDK4 kinase activity and functional inactivation of p53 via recruitment of HIPK2 kinase in Tax nuclear bodies.

Institute for Microbiological Research J-M Wiame, Université Libre de Bruxelles, Belgium

(C) 2014 Lodewick et al; licensee BioMed Central Ltd. This is an Open Access article distributed under the terms of the Creative Commons Attribution License (http://creativecommons.org/licenses/by/2.0), which permits unrestricted use, distribution, and reproduction in any medium, provided the original work is properly cited. The Creative Commons Public Domain Dedication waiver (http://creativecommons.org/publicdomain/zero/1.0/) applies to the data made available in this article, unless otherwise stated. doi:10.1186/1742-4690-11-S1-041
Cite this article as: Lodewick et al:: Post-translational modifications of
HTLV-1 Tax carboxy-terminal domain: role in cellular transformation. Retrovirology 2014 11(Suppl 1):041.
Submit your next manuscript to BioMed Central and take full advantage of:

- Convenient online submission

- Thorough peer review

- No space constraints or color figure charges

- Immediate publication on acceptance

- Research which is freely available for redistribution Submit your manuscript at
www.biomedcentral.com/submit C Biomed Central
- Inclusion in PubMed, CAS, Scopus and Google Scholar \\ () Biomed Central}

Published: 7 January 2014 